also had a very bad internal strabismus in both eyes, for which she was wearing convex glasses.

The case seems to me the more interesting now after reading Dr. Still's paper, as the age of the child does not tally with the ages of those reported and also I find no mention of the pediculus capitis as a cause of head-nodding. I may say that it was always when sitting up that she rolled her head, that the movement was from side to side, that the nods were quite $1 \mathrm{CO}$ to the minute, and generally lasted for a period varying between one and two minutes, but that there was no regularity of time between the spasms. I am, Sirs, yours faithfully,

North Kensington, W., August 1st, 1906. HAROLid MoWAT.

\section{MEDICAL PRACTICE IN SOUTH AFRICA AND ITS COMPLICATIONS.}

\section{To the Editors of THE LANCET.}

SIRs, - South Africa may be divided into two parts-the veld where there are no medical men and the towns where there are too many. One consequence of this unequal distribution of the profession is that the farmer on his "plaas" on the lonely illimitable veld has to treat most of the ailments of his household. He has a "pelikaan" for tooth extraction and his wife has her "apotheek"-a box full of the locally renowned Dutch medicines, ${ }^{1}$ such as Haarlem oil, Spanish fly, Hofman's drops, \&c., but these have of late been sufplemented by pink pills, bile beans, liquozone, and the host of modern remedies whose praise is in all the newspapers. Any old " tante" is the midwife for the neighbourhood and any farmer acts as gravedigger and undertaker when required. Sometimes a medical man has to be fetched from a great distance, but only rich families can afford this, for the fees are a guinea an hour, and ten hours are easily spent on the long roads. Medical knowledge gained by recognised methods of study and observation is, as a rule, not very highly esteemed by the "Boeren," who have a decided preference for the "wonderdokter," and in 1899 there was in the Transvaal a famous specimen of the lastmentioned class of practitioner. During the war he was in Cape Town and the Dutch Afrikanders there believed in him. His fame had, in fact, spread all over South Africa. The Afrikanders are like one big family - what happens in the Transvaal is soon known in Cape Town and vice versâ. "Dr. Eugen," as he was called, was quite a celebrity. From far and near the farmers travelled to Pretoria in 1899 to consult him. There was always a file of carts and wagons in his street and inside his door was a crowd peacefully waiting. A consultation always lasted five minutes and the fee was one guinea. As soon as the patient came forward the "dokter" laid both his hands on the former's head and something like an electric current was supposed to pass between healer and subject. The "dokter" knew at once what was wrong. He did not prescribe medicines as he was not possessed of any diploma, but the leading feature of his treatment consisted in regulation of the patient's diet. After his electrical diagnosis he sat in his big armchair and consulted his "spirits" about the different foodstuffs and beverages to be given or withheld. As a rule the farmer had to give up his coffee and wine, which was indeed a very hard trial to the Boer. During winter "Dr. Eugen" left Pretoria for the river Zambesi, where he lived on "drill fish," as they call the torpedo or cramp fish. In this way he got a new store of electricityfor the next season! Sometimes a rich farmer fetched him for an urgent case to his house. This was extremely expensive and the "doctor" would never take the ordinary food placed before the Boer and his family but only a fowl prepared in his own way. Oom Paul Kruger, the late President of the Transvaal Republic, had little faith in this "wonderdokter." He sent for him once but when Eugen began to "consult his spirits" the President asked him to what kind of spirits he was talking. "Are they in heaven?" "I do not think so," was the answer. "Then go," said Oom Paul.

Perhaps there is no part of the world in which patent medicines have such a vogue as in South Africa. Since the greater part of the population come into the world, live, and die without professional aid domestic medicines and some hereditary skill on the part of the farmers have the field much to themselves. No wonder that in this country the newspapers and periodicals, whether daily, weekly, or monthly,

Many pharmacentical chemists announce in gold letters on their windows that they sell Dutch medicines. contain so many advertisements of patent medicines and preparations for invalids. In a recent issue of the Cape limes, our leading newspaper, the following may be counted : (1) Savaresse's Sandal Capsules ; (2) Doan's Kidney Pills ; (3) Wolfe's Schnapps (pictures of 18 tired men!) ; (4) Carter's Liver Pills ; (5) Larola (for the skin); (6) Co-Do (for the mouth); (7) Montserrat; (8) Cockle's Antibilious Pills ; (9) Apiol and Steel Pills ; (10) Steedman's Soothing Powders (for children cutting their teeth); (11) Zam-Buk (in the news columns); (12) Bile Beans (in the news columns); (13) Sheldon's Digestive Tabules (for indigestion, dyspepsia, \&c.); (14) Chamberlain's Cough Remedy ; (15) Jones's Rheumaticuro (for sciatica); (16) Vichy-célestins (for gout, diabetes, \&c.); (17) Koppa (for the hair); (18) Ohicago Cold Cure (cures a cold in 24 hours); (19) Cooper Neuralgia Cure ; (20) Beecham's Pills ; (21) Towle's Pills (invaluable to ladies) ; (22) Wood's Great Peppermint Cure ; and (23) Dr. Shedon's New Discovery. It may here be remarked parenthetically that in the English papers such advertisements in the news columns are always marked $A d v$. Dutch papers may take them without any addition and as a rule with deceptive headlines. Once there was almost a quarrel between the editor and the director of ons Land; the former said: "My readers must see $A d v$. under such articles." "No," said the latter, "our shareholders have our first care." Dr. Sanden's electric belt occupies an advertisement space of about 50 square inches in every issue of our leading papers, Datch and English, but the pink pills have been much less con. spicuous of late. Perhaps this is caused by the harshness of our legislators. Before the new Custom tariff came into force on May 25th the agent for the pink pills paid only a trifling ad valorem duty on $7 d$. per 1000, this being the value as per invoice. But now he has to pay $£ l$ sterling for one pound avoirdupois, which is a very different thing. Of course, the farmers are the best customers for patent medicines, but as some of them read little more than their Bibles and a weekly church paper-De Kerkbode or $D_{e}$ Vereeniging -it is no wonder that even these religious papers get a good share of advertisements from the patent medicine vendors, so that next to a highly poetical and edifying explanation of some passage of Holy Writ there may be found a most prosaic paragraph on diseases and their treatment. Every druggist keeps a fairly complete stock of patent medicines as far as he can get hold of them, but some nostrums are not yet to be found in any drug store, because the agents do not wish to surrender any portion of their profits.

Medical men are not popular with the people, not even with the town people, partly because they are said to charge very high fees and partly because they are supposed to be required only for treating diseases of the teeth and for performing operations in which cutting and sewing are necessary. In cases of internal ailments the general idea is that the cheapest and easiest way is to go to a chemist and ask his advice. In 1901 and 1902 there was perhaps as much venereal disease in Cape Town as in any town on the globe, and most of these cases of syphilis and gonorrhœea were treated without a medical man. One druggist had 500 venereal patients in a month and all dealers in medicinal substances laid in full stocks of mercurials and santal midi to be disposed of to customers coming for advice and treatment.

As a rule the Boers succeed very well in rearing their large number of children. At Standerton there is a family with 29 children. When $I$ lived in a farming district in the Transvaal for a year I found that between 10 and 15 children in every house was the average and very few infants died. In Cape Town, however, more than 50 per cent. of the children die in their first year and even among the white people the death-rate is large. Our town council discussed the question in January last with the result that a duly qualified nurse now goes round to the houses where there are infants, examines the little ones, and gives the parents good advice.

Cape Town. I am, Sirs, yours faithfully, C. J. VAN RIJN.

\section{CARDIFF AND SWANSEA HOSPITALS.}

\section{Io the Editors of THE LANCET.}

SIRS,-The grounds for your unfavourable criticism in THE LANCET of July 28th of the management of the Swansea Hos pital as compared with that of Cardiff for the year 1905 appear to be the relative cost per bed as furnished by your correspondent. These were-Swansea, £71 19s.; Cardiff, 